\title{
From Overdecentralization to Overcentralization? Hungarian Experience in Handling the Crisis at the Local Level
}

\author{
Márton Gellén
}

\begin{abstract}
This paper provides a polemic interpretation of recent Hungarian public-administration reforms compared to the opinions that can be found in international scientific literature. The divergence of the various interpretations stems from the different perspectives on the historic context of the development path of the Hungarian municipal administration during the pre- and post-regime change period. The differences in the interpretation of the achievements of the regime change determine whether one would suggest a minor correction or a total replacement - if given the possibility. After briefly describing the public-administration legacy of the communist past and of the post-communist decades, the article delves into the analysis of the financial unsustainability of the highly decentralized local-government system. The analysis builds on the findings of international financiers that operate as policy-transfer powerhouses, as well. Bursting financial tensions led to Hungary's loan agreement with the IMF in 1996. Although the loan was paid back by 1998, internal systemic inefficiencies stemming from the uneasy compromises of the regime change still had their corroding effect, although vulnerable finances were veiled by occasional conjunctures in the domestic and international economy. In the year 2008, the country became virtually insolvent and again applied for an IMF loan. The IMF itself formulated certain measures to increase the efficiency of the overdecentralized local-government system. Unlike its predecessor, the government that stepped into power in 2010 had the political power to launch systemic corrections in the local-government system. The reforms contained a trade-off: the majority of local competences in exchange for fiscally consolidating local governments. This is labeled as a trade-off between efficiency and democracy by certain authors. It is a fact that the overdecentralized form of local public administration was inefficient and unsustainable. Now there is an opportunity to test whether an overcentralized public administration would be efficient.
\end{abstract}


Key words: democratization, politicization, centralization, decentralization, regime change

\section{Introduction}

Hungary used to be one of the most promising young democracies after the fall of the Berlin Wall. In fact, the first frays on the Iron Curtain appeared just 25 years ago on the border of Austria and Hungary ${ }^{1}$, followed by the sudden collapse of communist totalitarianism in the entire region (Jenei 2011). The key role of the country is connected to its central location but also to its vivid memories of an armed revolution against communism in 1956. Being a forerunner of Central and Eastern European democratic transition stands in contrast to how recent academic literature approaches public-administration reforms, including reforms of municipal (local government) administration. How come that recently Hungary has been connected to the "backslide of democracy" not only in the general media but also in academic literature (Sedelmeyer 2014, Ágh 2013, Hajnal and Csengődi 2014)? In the following, I make an attempt to throw light on the origins of the Hungarian administrative culture in order to clarify the context of the recent reforms affecting the administrative duties of local governments.

As can be seen from the first results of the LIPSE project ${ }^{2}$, the European pattern of handling the crisis of 2008 onwards is to decentralize administrative structures in order to decentralize the crisis, thus relieving the central administrative system. The Hungarian development path appears to be the opposite. Is it only party politics that lie behind, or is there perhaps a deeper rationale that can be elaborated through the argumentation of administrative science?

\section{What was public administration like during the communist period?}

The "knowledge of what works and what does not tends to be heavily context dependent" (Pollitt 2003, 122). This applies for long-term path-dependence theory, as well. Hungarian administration culture during "existing socialism" can be characterized by the following aspects:

\section{Dual character of power}

Duality of power used to be characteristic in all aspects of public life, creating a general schizoid setting. Everyday issues were administered by local officials, while

1 Celebrations of the $25^{\text {th }}$ anniversary of the historic event have been held recently: http://www. politics.hu/20140627/hungary-austria-slovakia-mark-25 ${ }^{\text {th }}$-anniversary-of-iron-curtain-opening/

2 Learning From Innovation in a Public Sector Environments (LIPSE) is an EU funded research project. For details please visit: www.lipse.org. 
strategic issues were determined in Moscow without any hint of public knowledge or discussion. (E.g., stationing nuclear weapons on Hungarian territory, decision on the structure of the domestic industry or attacking Czechoslovakia in 1968 etc.) The duality of governance was paralleled on the domestic level, as well. The country was formally governed by the government but in reality the administration executed decisions of the Party. This is a general pattern in Central and Eastern Europe and can be characterized as an "exogenous determinant" of political culture (Kitschelt et al. 1999, 12).

\section{Role of administration}

Decisions of the state authority were unquestionable. The role of administration was nothing else but replicating in practice whatever was decided by the Party. Neither law (the public-administrative court system was abolished in 1949) (Gellén and Patyi 2011) nor PA science was prepared for critical thinking (Gellén 2014). Such behavior was not tolerated, neither practical administrative measures that were "out of the line" nor "misbehavior" under a scientific disguise. The deterioration of PA science was tangible: the repetition of communist ideology was practically the only form of scientific "discussion" until the late 1980s (with the exception of a brief period in the late 1960s). First empirical studies (mostly unpublished) in sociology - and in any other science applying a sociological approach - were permitted in the 1980s. Other sciences, such as psychology (including social psychology), were labeled "bourgeois" and were banned.

\section{Favor - economics made oppression tolerable}

Widespread petty corruption and the culture of mutual favors made everyday life tolerable (Sandholtz and Taagepera 2005). Opportunism became a decisive cultural element: the possessors of power were interested in letting corruption flourish in order to minimize internal tensions (and avoid another 1956). Low-level and highlevel corruptions were mutually tolerated in order to maintain political stability. Hajnal presents petty corruption as an embedded cultural element of the state-society relationship in the post-regime change period. The social function of mass petty corruption - according to Hajnal's empirically supported findings - is to facilitate state-society relationships in terms of ensuring that actions of public administration and public service that otherwise ought to happen, would in fact take place. In such terms, corruption is a systemic element of the state-society relationship to overcome bureaucracy (Batory 2012). Urinboyev also presents petty corruption as an inseparable ingredient of everyday culture that is built on the imperative of individual and collective survival (Urinboyev 2013). 


\section{Regime change - with limitations}

By 1989, a pluralistic, democratic constitutional state came to life, having its first elections in 1990, whereas local governments had a vital role in the process of democratization. In 1989-1990, the "big bang" of the regime change affected the entire constitutional system - with certain flaws, however. In the formal sense, however, the constitution itself remained communist Act No. XX 1949 - with the statement in the newly amended preamble that the constitution itself is temporary. During the 1990s, Hungary appeared to be the forerunner of stability and prosperity, especially when compared to surrounding countries like the former Yugoslavia, Romania or the Soviet Union (Milanovic 1997, 2). The relative smoothness of the transition stemmed from the following:

- The 1956 revolution had a deep psychological effect on the communist elite, causing them to avoid all potential conflicts with the society. Unlike other communist elites in the region in the 1980s, the Hungarian political elite were very much aware that the situation was profoundly unstable (Niklasson 2006).

- While longing for internal stability, the communist state launched gradual reforms on the restoration of individual property and established a certain latitude for entrepreneurship. Such easing happened in connection with Hungary entering the IMF in 1982 and receiving loans from it (Act-Force Statute No. 6, 1982). The preparation for the regime change was given its impetus when a new company law was issued in 1986, which lay the tracks for privatization. Privatization began under communist control from the communist state to communist individuals. The communist influence was tangible in the most important fields of the economy, like telecom, media, culture, banking, foreign affairs, trade, justice, real estate and logistics (Ungváry 2008).

- The communist elite began preparations for a soft-version transition already in the early 1980 s, supported by 800,000 party members, approximately 50,000 internal secret contacts and 10,000-20,000 secret police (communist secret files are still unavailable to the public: some were re-classified, some have disappeared) (Takács 2013). With this background, the successor of the communist party won the democratic elections in 1994.

- The communist regime did not consider any unalienable human rights and implicitly rejected the right for local governance. Naturally at that time, state citizens did not have the right to vote for local assemblies. Furthermore, municipal borders were altered by Party decisions under the label of efficiency increase. With such reasoning, many municipalities lost their legal status and were artificially amalgamated with a bigger town or city. This practice has a long-lasting effect on the Hungarian public administration so that amalgamation of local governments is still a cultural and constitutional taboo. 
Designing the local-government system was also part of the smooth transition. The law on local governments was issued by the new Parliament in 1990, but it was prepared by the Ministry of Interior before the regime change happened (Gellén 2012, 154). Throughout the years of the 1990s it turned out that the Socialist Party could effectively use local politics for maintaining its territorial network of interests and cadres. This turned out to be obvious later on when former heads of local soviets (former Party commissars) successfully rebooted their former careers as town mayors en masse (Ellis 1997). Political contradictions of this transitional period offer an understanding of why the Hungarian path to administrative development did not prove to be a continuous success story throughout the ensuing decades (Orenstein 2008). The following are among the most important strategic factors of the post-regime change period:

Regime change happened in two phases. The first and most important phase happened before Rechtsstaat values could crystallize, meaning that the first phase was done before the political regime change. The second phase took some time to unfold since the new democratic institutions took time to develop, and their legal guarantee systems took further time to provide practical protection. This phase difference involved that newly established ownership rules and other legal institutions provided entrenchment for those who successfully transferred their political clout into economic power. The non-democratic nature of this phenomenon was soon recognized by foreign observers, as well (Ayres and Braithwaite 1992, 7). The proposition of administrative and political science would have been the opposite of what actually happened: setting the rules first, then playing the game.

Administrative and welfare systems came under unbearable pressure because of social and economic collapse. The first correction of the newly established democratic administration and public-services system took place in 1995 (Kornai 1996). In 1996, Hungary had to re-enter a standby loan agreement with the IMF. The nature of post-communist systemic meltdown is well-known in the entire Central and Eastern European region of this time:

- Gigantic state-owned enterprises collapsed after the immediate disappearance of foreign markets (primarily due to the lack of solvency of post-Soviet partners) (Román 2005, 55-56).

- Large public-sector education, health and pension systems were only modestly changed since it was these systems that absorbed the masses leaving the labor market (OECD 2008, 57-139).

- Privatization was not under social control, apart from sporadic victories, and mass privatization led to the loss of work competence and the loss of markets.

- The remaining work force was partly moved to services or low-added-value industries. 
A so-called dual economy was conserved, with approximately 700,000 microenterprises that had little real chance for growth, and with a few (mostly foreignowned) $)^{3}$ multinationals that brought production to Hungary (Pavlínek 2004).

\section{Public-administration culture}

Especially in the first period of development, Hungary was involved in various international technical-assistance projects regarding public administration. The Support for Improvement in Governance and Management (SIGMA), in conjunction with the EU and the Organization for Cooperation and Development (OECD) and Pologne, Hongrie Aide a la Reconstruction économique (PHARE: EU pre-accession program) were helping Hungary comply with the European administrative area's requirements in the Union accession program, and the annual reports system moved the country into action (Sobis and de Vries 2009). Due to or despite the massive foreign assistance, the development of the Hungarian public-administration culture muddled along rather slowly. In terms of public-administrative culture, legalism is identified by a group of theorists as an appropriate label for Hungarian PA culture (Hajnal 2003; Hințea et al. 2006). Rechtsstaat culture (a constitutional state in which the exercise of power is governed by law) appears to be an inseparable attribute of Hungarian public administration (Hajnal 2008, 132) Rechtsstaat culture in itself is a positive factor, and even in its contracted format, it used to have a beneficial impact during the 1970s and 1980s since it represented a higher standard to the Soviet-style administrative culture. The existing remains of Rechtsstaat culture - within narrow barriers - offered a certain alternative to the over-politicized operations of the Hungarian public administration. Drechsler states that Weberian public administration worked as a protective and supportive vehicle for the young democracy and also for the new market economy (Drechsler 2005). Thus, during the communist period, a distorted Rechtsstaat culture mixed with the traditional irresponsiveness of a Soviet-style public administration, created a rather stiff combination. Besides legalism as the main factor of PA cultural setting, there is another trend identified by PA theory: gradual politicization that tangibly emerged in the mid-2000s (Meyer-Sahling 2006).

\section{Inherited distortions of the local government system between 1990 and 2010}

According to the new legal setting enacted in 1990, the local-governmental system was composed of two tiers: at the upper tier there were the nineteen counties and

3 Dual economy is a systemic market-development failure characteristic in the Central and Eastern European region - according to Petr Pavlínek (2004) - whereas foreign direct investment creates a separate economy upon the domestic economy, and the two have very limited connections with each other. 
the capital city of Budapest and at the lower municipal tier almost 3,200 local governments run by elected councils (Hajnal, 2012, 289).

The local governments had a high political legitimacy supplemented with financial autonomy. Political and legal autonomy was untouched throughout the decades, but financial latitude was gradually cut back by various governments. To give an impression on the process I present the most vivid examples:

- The path of development contained the abolition of social-security local governments in 1998 (Act No. LXXXIV, 1991), an independent local-government system that operated so inefficiently that its operations erased a decisive percentage of national social-security asset value (Munkaügyi Levelek 1998).

- The re-distribution of local income taxes was also cut back in the 1990s (Horváth et al. 2014).

- Legal charges collected by county local governments were re-directed to the central tax-authority in $2007 .^{4}$

Besides the financial contraction, the tasks of the local governments tended to widen throughout the years. The widening process was enabled by the opportunity to increase the amount of "delegated competences" with insufficient central funding or no funding at all. The two parallel processes resulted in a phenomenon that domestic public-administration theory called "conflict container" (Pálné 1990).

The high autonomy of the municipal sector contributed to a certain resource of fiscal efficiency for the incumbent governments as the local governments became bearers of tasks without financing. Such delegated tasks disappeared from the budget of the central government that has been under permanent financial pressure. Since the municipalities have diverse resources for additional revenues, certain local governments could survive such government measures in a financially intact position. However, on the systemic side, the unfunded delegation of tasks turned out to be unsustainable. While in 2005 the gross debt of municipalities added up to $1.9 \%$ of the GDP, in 2009 it was $4.1 \%$ (Vigvári 2011, 61).

4 For further details see: http://m.hvg.hu/app//gazdasag/20070517_apeh (last accessed: 11 September 2004). 


\section{Diagram 1}

Gross municipal liabilities (billion HUF)

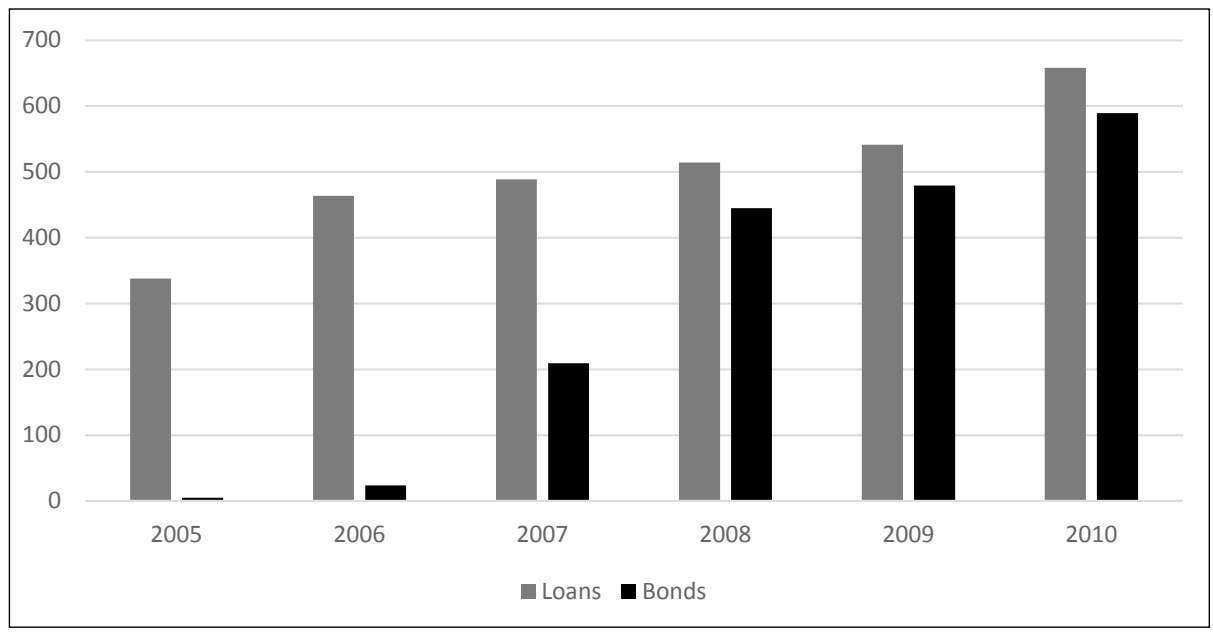

Source: http://vastagbor.blog.hu/2012/10/29/atvallalja_az_allam_az_onkormanyzatok_adossagat (last accessed 25 August 2014.)

Diagram 1 shows the tendency of how local-government liabilities increased over the years of 2005-2010. The reason why issuing municipal bonds developed so rapidly was that legal provisions applied a cap on bank loans, thus local governments reaching the cap issued bonds for external financing. To a certain extent, this was already a kind of decentralization of fiscal crisis before the crisis. After the year of 2008, the tendency of crisis decentralization even accelerated throughout the policy pattern of "conflict container" that was extensively exploited already years before the crisis (Vigvári 2010, Gál 2011, Horváth et al. 2014).

According to Vigvári (2010), the currency composition of the loans was nothing else than a public-financing nightmare. The proportion of bond issues with regard to currency until 2008 was the following:

- EUR: $1 \%$

- HUF: $13 \%$

- CHF: $86 \%$

From 2008 (Q3) to 2009 (Q3) the currency composition of newly issued municipal bonds was the following:

- EUR $63 \%$

- HUF: $22 \%$

- CHF: $15 \%$ (Vigvári 2009). 
It has to be stated that certain local governments provided best practices in terms of due diligence and did not engage in any uneven financial practices. Typical examples are the ones that have significant industrial companies on their territory that constantly provide local income taxes (such prosperous municipalities are Budaörs, Paks, Százhalombatta, etc.). However the good examples did not change the overall picture that the entire sector had to be bailed out. The local governments tried to justify their practices arguing that their quest for additional external financing came from their ambition for accessing EU funds for local development. In many cases this was true, but it did not change the unsustainable character of the municipal sector’s financial status (Vigvári 2009).

\section{The position of international financial institutions on the level of decentralization}

The "conflict container" nature of the overdemocratized and overdecentralized local-government system aroused the attention of international financial institutions, as well, when the financial crisis automatically pinpointed the financial defects of the Hungarian system. Two formerly active providers of technical assistance and public-administration reform ideas returned to Hungary in 2008. First of all, in 2008 the Hungarian government agreed with the IMF to reduce central-budget transfers to the local-government sector. Already in the early 2000s IMF tended to advertise the World Bank position that decentralization was a beneficial administrative principle in terms of local governments (Deither 2000). However, - as the World Bank analyst puts forth - decentralization in Hungary was overdone. Hungary became one of the most decentralized countries of Central and Eastern Europe and should have been contrasted with Slovakia, which was one of the least decentralized countries, during the decade of transition from socialism to market (Deither 2000, 3-5). When Hungary was hit by the international economic crisis in 2008, internal inefficiencies suddenly came to the surface. In order to avoid fiscal insolvency, Hungary signed a stand-by loan agreement with the IMF. According to the first country report under the loan agreement ${ }^{5}$, the following structural reform steps - affecting public administration - were agreed upon:

- Reducing the government's financial needs,

- Cost-cutting in central government,

- Taking steps to eliminate redundant transfers and subsidies provided by different government levels,

- Encouraging local government to seek economies of scale by cutting central government transfers (in the 2010 budget),

- Reducing the size of local councils.

5 http://www.imf.org/external/pubs/ft/scr/2009/cr09105.pdf (last accessed 12 August 2008) 
As can be seen from the list, the promise of efficiency gains was not seen in granting more autonomy to local governments and government organs (as well as agencies) but in merging them. A sort of correction of the level of decentralization appears to be part of a constant policy of the IMF and the World Bank. In fact, the natural request of international lenders for higher fiscal control on the public administration, including the local governments, was incorporated into the IMF-Hungary cooperation (IMF 2009, 12). However, reducing the number of local governments was out of the question. This stems from the culturally embedded approach of the constitutional right for local governance. Therefore amalgamations or mergers directed from above were unimaginable, unlike in the Netherlands, for example.

The Hungarian local government system has been labeled inefficient by the OECD, as well. The critique articulated by the OECD was "underused economies of scale and lack of policy coherence at the local level" (OECD 2008, 207), meaning that the local governments are too numerous, too fragmented, and no government institution has power to control their policies in content. The other critical finding by the OECD was "overlapping responsibilities at the intermediate level" (OECD 2008 , 207). Both critical remarks were absolutely valid. At that time only legal control was available above local-government rulings in the case of unlawfulness.

Apart from the inefficient character of the Hungarian local government system, having high autonomy fulfilled the European Charter of Local Self-Government and prescriptions of utilizing local social energies.

\section{Centralization as a response to the crisis}

Parliamentary elections in April 2010 radically transformed the country's party system. The conservative Fidesz party received a two-third majority, and the Hungarian Socialist Party (MSzP) was pushed to second place with considerably fewer seats. The two centrist parties that had been in existence since 1990, the Hungarian Democratic Forum (MDF) and the Alliance of Free Democrats (SzDSz), lost out to two new parties, Jobbik, on the extreme-right, and Politics Can Be Different (LMP), a liberal protest party. ${ }^{6}$ The newly emerged monocentric political structure offered a historic chance for the government to make all structural changes it found necessary. The new political leadership had the ambition of correcting the birth defects of the regime change that were definitely numerous.

The first part of the reform was to avoid a pattern to unfold that would have been similar to what happened in Greece. ${ }^{7}$ Part of the reform was to re-arrange the unsustainable nature of the local government - central-government coopera-

6 www.valasztas.hu, the official site of Elections' Office.

7 http://www.economonitor.com/edwardhugh/2010/01/22/hungary-isnt-another-greecenow-is-it/ 
tion according to the IMF requests. The standard recipes, however, (amalgamation) could not have been applied in the case of local governments due to the culturally embedded interpretation of the constitutional notion of the right for local governance. It is also understandable that the central budget - under the close control of the IMF - was not in the position to bail out the local-government sector without imposing financial and policy control.

In a paper prepared for an IMF conference on decentralization in Hungary and in Slovakia, Deither (2000) argues that central control on local government budgets should be enhanced by strict regulations, improved accountability and by the fiduciary responsibility of the central budget (Deither 2000, 13).

The government launched a vast PA-reform program (Magyary Plan) under Government Decree 1207/2011 (VI. 28.) in 2011. The reform program aims at increasing the overall efficiency of the entire public-administrative system throughout modernizing its tasks, personnel, processes and structure. These structural reforms can be labeled primarily as centralization, with the ambition of saving costs and having a firm control on policy processes. The reform that took place in 2011-2013 re-concentrated most of the competencies from local government offices. It is important to mention that there has been a consensus for a long time in domestic public-administration legal theory that "original competences" of local governments have to be divided from "delegated competences". The most important difference was that "original" competences originated from the constitution - thus could not be changed - and the democratically elected local assemblies were entitled by them (Szabó 2012, 30). "Delegated competences", on the other hand, were regulated in lower-level legal sources, and they addressed the local notary. Local notaries were not the employees of the local assembly, nor of the local mayor. The "re-concentration" maneuver took the short and simple route to increase efficiency and transparency towards international lenders: since formal municipal independence was untouchable, the Parliament decided to remove the delegated competencies from the municipal notaries and concentrated the competencies at the newly established district administrations (townships). Townships became the local branches of the County Government Offices, and they became responsible for all public administrative issues that used to be delegated to the local governments. This somewhat hollowed out the local governments' administrative role since approximately $75 \%$ of their case load consisted of delegated public-administrative cases. Taking into account the removal of such a decisive portion of the competencies of the local governments, their systemic local role has to be reconsidered for at least two reasons. Local governments used to have enormous voluntary tasks (maintaining secondary schools, etc.) and they still have significant "own" revenues, such as local taxes. Since local identity is usually considerably strong in the Hungarian society, these factors should not be excluded from considering the next steps of the reform. As Hajnal and Csengödi formulate the local element of the reform, 
Local self-governments' scope of duties and competencies (many important functions in the field of operating secondary education and health-care facilities) were dramatically reduced by transferring them to the newly created District Government Offices (strictly and hierarchically subordinate to County Government Offices). Later on, additional administrative tasks and the related bureaucratic capacity of local government offices were transferred to the District Government Offices, too. Elected and decentralized county-level self-governments, as a result, lost most of their previous - and already quite modest - functions (Hajnal and Csengödi 2014, 49).

Hajnal and Csengödi argue that the centralization process is politicization. I argue, however, that politicization and higher central control is a primary tool for controlling the crisis (Camillus and Deepak 1991).

Transferring local administrative tasks to local offices of centralized institutions can be observed through the divergence of central- and local-government budgets' shares of the GDP.

\section{Diagram 2}

Comparing central- and local-government expenditures in percentage of GDP in Hungary

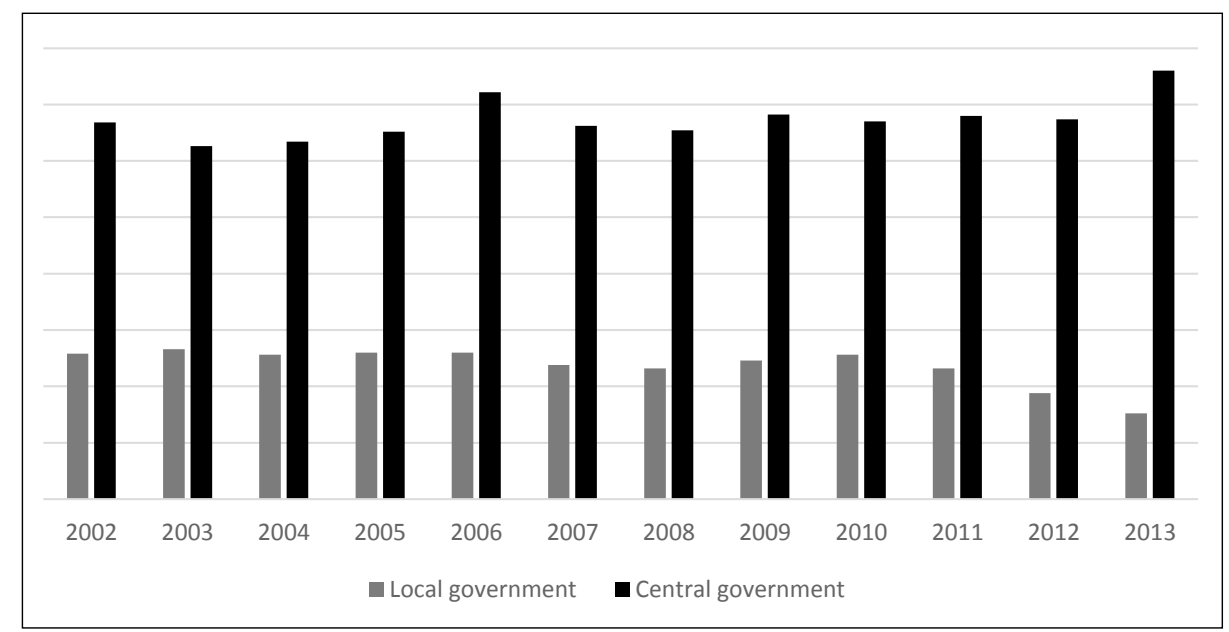

Source: EUROSTAT ${ }^{8}$

8 http://epp.eurostat.ec.europa.eu/tgm/refreshTableAction.do?tab=table\&plugin $=1 \&$ pcode $=$ te c00023\&language $=$ en (last accessed 12 September 2014) 
Looking at Diagram 2, it might be surprising at first glance that after 2008 when the central budget became practically insolvent and an IMF loan agreement had to be signed in great haste -, the relative proportion of local budget expenditures could still slightly increase until 2010. This shows that the central fiscal administration had little influence on local budgets to contract expenditures. From the fiscalmanagement point of view this is a major systemic uncertainty that was forecast by IMF and OECD analysts. It is also telling to see in Diagram 2 how central and local expenditures diverge from 2011 onwards. External finances for local governments became less available as their general credit position deteriorated; therefore local expenditures have been contracted gradually but 2 years lagging behind the central budget's restrictions. In 2013, the Hungarian central budget paid back the final installment to the IMF' this was the same year when from 1 January, the former local government delegated competencies, and the connected finances were relocated.

A more detailed picture appears when the internal composition of local finances is presented.

\section{Diagram 3}

Local revenues in \% of total finances

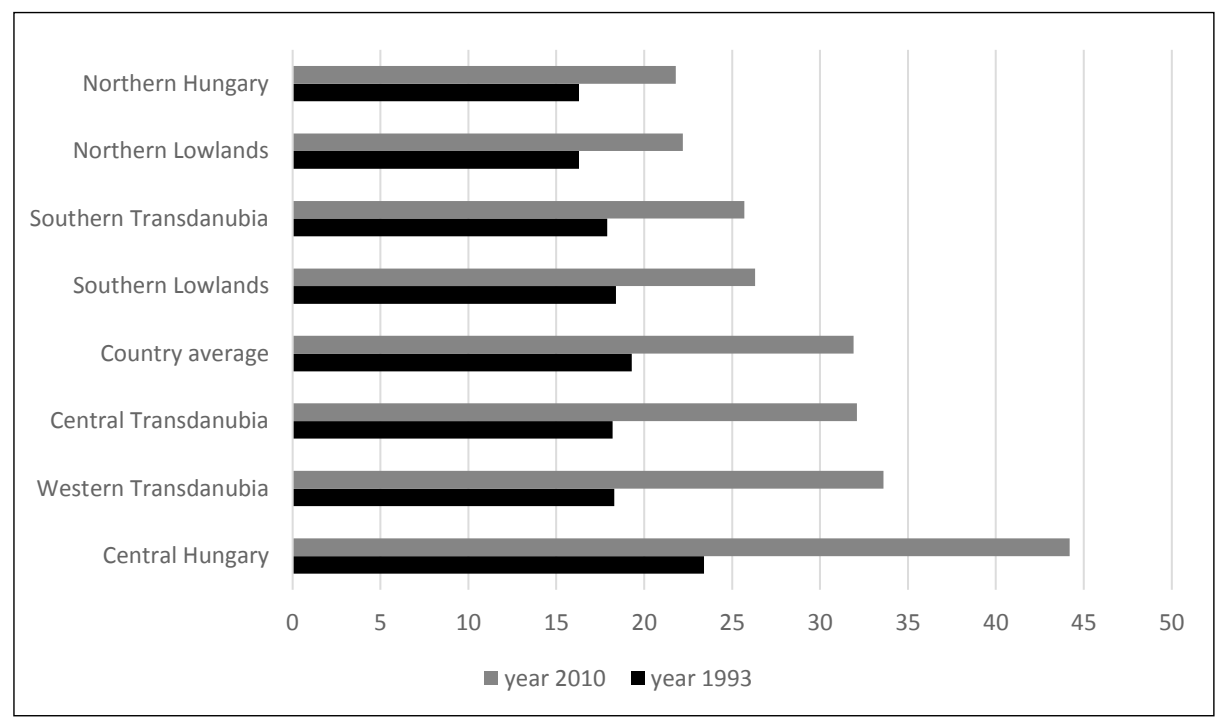

Source: Horváth et al. 2014, 137

Diagram 3 shows the relative position of local revenues (mostly: local taxes) compared to locally spent central-budget transfers in a geographical breakdown for the years 1993 and 2010. The level of inequality can be seen between local-

9 http://www.imf.org/external/np/fin/tad/extrans1.aspx? memberKey1=415\&endDa te $=2014-08-31$ (last accessed 12 September 2014) 
government abilities to compensate for the withdrawal of central funding with the increase of local revenues. In 1993 the proportion of local taxes varied between $16.3 \%$ (Northern Hungary) and 23.4\% (Budapest and Pest County), while in 2010 these figures increased to $21.8 \%$ and $44.2 \%$. Territorial policy tended to agree with IMF recommendations that transfers to local governments should be decreased, but this led to an increased geographical inequality that was hardly compensated by the resource-distribution policy of EU cohesion funds. It can be concluded that centralization affecting local government competencies and finances appears to be a logical organizational response to an existing fiscal challenge. The long-term effects, however, cannot be projected yet.

\section{Closing remarks}

The re-centralization of municipal competencies appears to be in line with the OECD findings of 2008, and it also has an impact on state financing. The sharp increase of municipal indebtedness can be halted and a new, transparent system is about to be elaborated regarding $75 \%$ of the local governments' responsibilities. Internal transparency and closer control might be more acceptable for state financers than a complicated patchwork of local governments. Previously the central fiscal administration had no influence on financial decisions of local governments even if their financial decisions threatened the interest of stable state financing. Centralization has a certain cost, though local control on local issues will be certainly weakened even if one takes into account that the so called "delegated tasks" used to be allocated to the local level upon a decision that was not made by the local assemblies. As local elections will be held on 12 October 2014, the effect of centralization can be immediately measured on the decrease of the activity of local politics. While on previous local elections the gross number of local candidates for assembly seats and mayor positions were around 100,000 nationwide, the current figure is 58,000. ${ }^{10}$ A similar decrease characterizes mayor positions: it appears that there are no candidates in around 400 local governments - mostly villages. ${ }^{11}$ One might agree that this is harmful to local democracy but it can also be argued that local rent-seeking possibilities also decreased.

Jenei views the re-centralization process as a development path whereas stabilization and steady development characterized the path until 2002. Afterwards, the development path turned towards marketization and later to state minimalization that lasted until 2009. From 2010 onwards, the other extreme of the pendulum effect can be witnessed in order to undo what minimalization measures distorted. (Jenei 2009) In the meantime, however, the financial crisis had to be handled some-

10 http://www.inforadio.hu/hir/belfold/hir-665771 (last accessed 12 September 2014).

$11 \mathrm{http}: / /$ www.magyarpolgarmester.hu/? site $=104 \& \mathrm{c}=3890 \& \mathrm{menu}=\mathrm{c02}$

(last accessed 12 September 2014). 
how while some genetic defects of the administrative system had to be corrected that came to the surface suddenly. Currently, one cannot speculate on how long the newly centralized system will work. What can be concluded, though, is that in the short run it appears to work because it contributed to eliminating local fiscal uncertainties.

The centralization has certain risks, as well: there are already a certain number of examples. It is common in these failure cases that they show how important the "conflict-container" nature of decentralized local entities used to be. The news on such project failures would normally be only isolated local news with not much hype about them. The centralized structure, however, automatically increases the magnitude of project failures to policy failures while such failures appear in the realm of high-profile political communication, as well. An example that has a massive political impact is the following. Primary and secondary schools use the same software for their internal educational administrative operations. The software ought to have been purchased by a single centralized institution through public procurement. The procurement process could not be completed in time because of legal remedy procedures at the Public Procurement Authority. Therefore all schools and secondary schools (being more than $6 \%$ of the politically active population, right before the local elections) face serious challenges in their everyday work. ${ }^{12} \mathrm{~A}$ normal project failure immediately became a policy failure with massive political impact.

Leaving political argumentation to political scientists, it is to be stated that Hungarian administrative culture - described above - might react to centralization as returning to the normal state of public administration, whereas civil service has to replicate in practice whatever the political authority proclaimed in theory. This might add up to a rigid, non-responsive combination of monocentric politics and highly hierarchic central administration. This should be avoided - not necessarily through "re-decentralization" in the short run but by increasing internal and external transparency, increased citizen participation in central-administration processes and by nurturing internal administrative innovations. Transparency might serve as a tool to make centralized institutions more flexible and accountable. Without sufficient transparency on administrative issues and projects, citizen claims tend to instinctively target the central government, which would normally be interested in increasing the level of administrative transparency in order to redirect citizens' claims to the lower echelons of the administration - where they belong to.

12 For further details see: http://www.napigazdasag.hu/cikk/22338/

(last accessed 12 September 2014) 


\section{References}

Ágh, Attila. 2013. "Bumpy Road of the Hungarian Administrative Reforms: From Political Over-Centralization to Public Policy Failures." Politika i Uprava 13(4), 1149-1170.

Ayres, Ian and John Braithwaite. 1992, Responsive Regulation: Transcending the Deregulation Debate. Oxford: Oxford University Press, UK.

Batory, Agnes. 2012. "Why Do Anti-Corruption Laws Fail in Central Eastern Europe? A Target Compliance Perspective." Regulation \& Governance 6, 66-82.

Camillus, John C. and K. Deepak Datta. 1991. "Managing Strategic Issues in a Turbulent Environment.” Long Range Planning 24(2), 67-74.

Deither, Jean-Jacques. 2000. "The Effectiveness of Decentralization in Hungary and Slovakia." Washington DC: World Bank. Paper prepared for the IMF Conference on Decentralization: Experience, Issues and Policies, 20-21 November.

Drechsler, Wolfgang. 2005. "The Rise and Demise of the New Public Management." Post-Autistic Economics Review 33, 14 September. Available at http://www. paecon.net/PAEReview/issue33/Drechsler33.htm (last accessed 25 August 2014).

Ellis, Mark S. 1997. "Purging the Past: The Current State of Lustration Laws in the Former Communist Bloc." Law and Contemporary Problems 59(4), 181-196.

Gál, Erzsébet. 2011. "Kell-e szabályozni az önkormányzati hitelfelvételt? A magyar eset tanulságai" [Shall local government debts be regulated? Conclusions of the Hungarian case] Pénzügyi Szemle 56(1), 124-144.

Gellén, Márton. 2014. "Public Administration in a Continental European Legalistic Setting: The Hungarian Case." Teaching Public Administration 32(2), $111-126$.

Gellén, Márton. 2012. Közigazgatási reformok azállamszerep változásainak tükrében. $\mathrm{PhD}$ thesis. Available at http://doktiskjog.sze.hu/images/doktori.hu-ra/gellen\%20marton\%20vedes/PhD_dolgozat_GellenMarton_vegleges.pdf (last accessed 10 September 2014).

Gellén, Márton and András Patyi. 2011. "Efficiency and Judicial Procedures: Friends or Foes? Analyzing the Relationship of Efficiency and Judicial Procedures in Theory and in Practice." The NISPAcee Journal of Public Administration and Policy (Special Issue: Education and Training: Preparing for the Future of the Public Sector in Europe) 4(2), 27-86.

Hajnal, György. 2008. "Public Management Reforms: Hungary." In Geert Bouckaert, Juraj Nemec, Vitalis Nakrošis, György Hajnal and Kristiina Tõnnisson (eds). Public Management Reforms in Central and Eastern Europe. Bratislava: NISPAcee Press, 121-150. 
Hajnal, György. 2003. “Diversity and Convergence: A Quantitative Analysis of European Public Administration Education Programs." Journal of Public Affairs Education 9(4), 245-258.

Hajnal, György, 2012. Hungary. In: Government Agencies: Practices and Lessons from 30 Countries. (eds). Verhoest, K., Van Thiel, S., Bouckaert, G., and Laegreid, P. England; Palgrave; Macmillan. 289.

Hajnal, György and Sándor Csengődi. 2014. "When Crisis Hits Superman: Change and Stability of Political Control and Politicization in Hungary." Administrative Culture 15(1), 39-57.

Hințea, C, D. Ringsmuth and C. Mora. 2006. "The Reform of the Higher Education Public Administration Programs in the Context of Public Administration Reform in Romania." Transylvanian Review of Administrative Sciences 16(E), $40-46$.

Horváth, Tamás M., Gábor Péteri and Pál Vécsei. 2014. "A helyi forrásszabályozási rendszer magyarországi példája 1990-2012" [Hungarian example of regulating local revenues 1990-2012]. Közgazdasági Szemle 61 (February), 121-147.

IMF. 2009. First Review Under the Stand-By Arrangement and Request for Modification of Performance Criteria. IMF Country Report No. 09/105.

Jenei, Gyorgy 2011. "The Opening of the Hungarian Border for the East German Refugees in 1989: A Public-Policy Analysis of a Key Decision." Halduskultuur 12(2), 113-125.

Jenei, György 2009. "A közintézményi menedzsment reformjainak torz magyar folyamatai az EU tagállamok mércéjén: hiányok, okok, megoldási javaslatok" [Distorted Hungarian processes of public management reforms measured by the examples of the EU members: gaps, reasons, propositions]. Uj Magyar Közigazgatás 6-7, 4-11.

Kitschelt, Herbert, Zdenka Mansfeldova, Radoslaw Markowski and Gábor Tóka. 1999. Post-Communist Party Systems: Competition, Representation and InterParty Cooperation. Cambridge: Cambridge University Press, UK.

Kornai, János. 1996. "Paying the Bill for Goulash Communism: Hungarian Development and Macro Stabilization in a Political-Economy Perspective." Social Research 63(4), 943-1040.

Meyer-Sahling, Jan H. 2006. "The Institutionalization of Political Discretion in Post-Communist Civil Service Systems: The Case of Hungary." Public Administration 84(3), 693-716.

Milanovic, Branko. 1997. Income, Inequality and Poverty during the Transition from Planned to Market Economy. Washington D.C.: The International Bank for Reconstruction and Development/The World Bank, USA. 
Munkaügyi Levelek [Labour Letters]. 1998. Available at http://munkaugyilevelek. hu/1998/08/megszuntek-a-tb-onkormanyzatok/ (last accessed 11 September 2014.

Niklasson, Thomas. 2006. Regime Stability and Foreign Policy Change. Interaction between Domestic and Foreign Policy in Hungary 1956-1994. Lund Political Studies 143. Lund: Department of Political Science, Lund University, Sweden. Available at http://www.svet.lu.se/fulltext/niklasson.pdf (last accessed 11 September 2014).

OECD. 2008. Reforms for Stability and Sustainable Growth: An OECD Perspective on Hungary. Paris: OECD Publications.

Orenstein, Mitchell A. 2008. "Postcommunist Welfare States." Journal of Democracy 19(4), 80-94.

Pavlínek, Petr. 2004. "Regional Development Implications of Foreign Direct Investment in Central Europe." European Urban \& Regional Studies 11(1), 47-70.

Pálné, Kovács I. 1990. Helyi politika [Local politics]. Budapest: Akadémiai Kiadó.

Pollitt, Christopher. 2003. "Public Management Reform: Reliable Knowledge and International Experience." OECD Journal on Budgeting 3(3), 121-136.

Román, Zoltán. 2005. "Does Competitiveness of our Economy Improve or Weaken? Our Productivity and Competitiveness in the Light of Statistics." Gazdaság és Statisztika 17(1), 51-62.

Sandholtz, Wayne and Rein Taagepera. 2005. "Corruption, Culture and Communism." International Review of Sociology 15(1), 109-131.

Sedelmeyer, Ulrich. 2014. "Anchoring Democracy from Above? The European Union and Democratic Backsliding in Hungary and Romania after Accession." Journal of Common Market Studies 52(1), 105-121.

Sobis, Iwona and Michiel S. de Vries. 2009. The Story Behind Western Advice to Central Europe During Its Transition Period. Bratislava: NISPAcee Press, 40-41.

Szabó, Lajos. 2012. Az önkormányzatok feladatrendszere. In: Zoltán Barabás et al. (eds). Közigazgatási szakvizsga: Önkormányzati közigazgatás tankönyv Nemzeti Közigazgatási Intézet [Task System of Local Governments. Coursebook for Civil Service Professional Training]. Budapest: National Institute for Public Administration, 27-34. Available at http://uni-nke.hu/downloads/ egyetem/vtki/onkoritk.pdf (last accessed 11 September 2014).

Takács, Tibor. 2013. "Állambiztonsági ügynökhálózat és az 1963-as amnesztia" [State Security Agent Network and the 1963 Amnesty]. Betekintö [Journal of the State Security Historical Archives] 3. Available at http://www.betekinto. hu/2013_3_takacs (last accessed 10 September 2014). 
Ungváry, Krisztián. 2008. Elhallgatott múlt: A pártállam és a belügy: A politikai rendörség müködése Magyarországon, 1956-1990 [Silenced Past: The Party State and the Ministry of the Interior: The Operation of the Political Police in Hungary, 1956-1990]. Budapest: Corvina Publisher, 1956 Institute.

Urinboyev, Rustamjon. 2013. Living Law and Political Stability in Post-Soviet Central Asia. A Case Study of the Ferghana Vally in Uzbekistan. Lund. Lund University, Sweden.

Vigvári, András. 2010. "Is the Conflict Container Full? Problems of Fiscal Sustainability at the Local Government Level in Hungary." Acta Oeconomica 60(1), 49-77.

Vigvári, András. 2009. "Atipikus önkormányzati eladósodás Magyarországon." [Atypical Indebtedness of Local governments in Hungary]. Közgazdasági Szemle 61(6), 709-730.

Vigvári, András. 2011. Önkormányzati pénzügyek. Hazai kihivások és nemzetközi példák. Állami Számvevőszék Kutató Intézete. (Local Government Finances. Domestic Challenges and International Examples. Research Institute of the State Audit Office), Budapest. 